\title{
TATALAKSANA STOMATITIS ALERGICA PADA PENDERITA YANG MENGALAMI STRESS (Management of Allergic Stomatitisin Patient with Stress)
}

\author{
Raziv Ganesha*, Diah Savitri E**, Hening Tuti Hendarti**
}

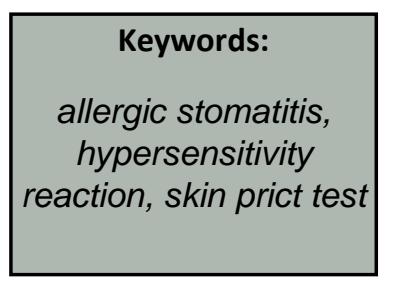

\begin{abstract}
Introduction:Allergic stomatitisis ahypersensitivity reaction caused by allergens, such as drugs, food, and dental materials. Manifestation allergic reaction to food in oral cavity can be recurrent ulcer.

Purpose:This case report pupose to report management allergic stomatitis in Stress condition.

Case:female was a 44-year-old with complaintmany stomatitis in oral cavity. Patients say often since \pm 6 years ago without knowing the cause. Stomatitis often moving location but also in the same site. On intra oral examination found ulcer multiple, variant size, irregular shape, paintfull.

Management:the patient performed examination of total $\lg E$ with a result of 642.98 (normal<150), skin prick test in patients results positive on dust house, dog hair, cotton, beef, cow's milk, chicken egg yolk, shrimp, milkfish, pindang, chocolate, and peanuts. Patients given aloe vera extract oral rinse at the first visit, then after skin prick test was given methylprednisolone, hepaprotector caplet, multivitamin B-Complex plus Zinc. Patients are also given education and instruction to avoid a food become allergic.

Conclusion: Allergic Stomatitis diagnosis requires a complete history and supportive examination. In this case, the treatment requires good cooperation between the patient and the dentist so that treatment can be done thoroughly.
\end{abstract}

\section{PENDAHULUAN}

Alergi atau reaksi hipersensitivitas, pertama kali dikenalkan oleh Von Pirquet pada tahun 1906, yang menyatakan bahwa perubahan aktivitas imunitas dan reaksi hipersensitivitas di induksi oleh antigen atau alergen. Alergi merupakan respon imun spesifik yang tidak diinginkan dan ditandai dengan adanya reaksi hipersensitifitas (peningkatan kepekaan) terhadap suatu alergen. Alergen adalah suatu benda asing yang masuk ke dalam tubuh dan menimbulkan perubahan. ${ }^{1}$ Stomatitis alergika merupakan suatu reaksi hipersensitivitas yang disebabkan oleh alergen penyebab seperti obatobatan, makanan, bahan kedokteran gigi (bahan restorasi, prostetik, alat ortodonti, merkuri, akrilik, cobalt. $^{2}$

Alergi makanan merupakan reaksi simpang makanan akibat respon imunologik abnormal tubuh. Pada rongga mulut manifestasi reaksi alergi terhadap makanan dapat berupa ulcer kambuhan. Alergi terhadap makanan dapat melalui berbagai jalur reaksi alergi tipe 1 (antibody IgE spesific), tipe 2 (reaksi antigenantibody dependent cytotoxic), tipe 3 (reaksi

* Oral Medicine Department, Faculty of Dental Medicine, Universitas Mahasaraswati

** Oral Medicine Department, Faculty of Dental Medicine, Universitas Airlangga

Korespondensi: raziv.ganesha@unmas.ac.id 
kompleks antigen-antibody), dan tipe 4 (tipe lambat). Alergi makanan yang sering terjadi adalah melibatkan reaksi tipe 1 dan tipe 4, atau kombinasi keduanya. ${ }^{3,4}$ Lokasi stomatitis alergika bisa terjadi di seluruh rongga mulut, akan tetapi lokasi yang paling sering adalah pada mukosa labial, gingiva, bibir dan lidah. ${ }^{2}$ Prinsip terapi pada stomatitis alergika adalah relief of pain, mengurangi durasi ulsernya, dan memperbaiki fungsi normal rongga mulut. Pengobatan stomatitis alergika bisa menggunakan kortikosteroid topikal atau sistemik. ${ }^{4}$

\section{TUJUAN}

Tujuan laporan kasus ini adalah untuk melaporkan mengenai tatalaksana stomatitis alergica karena alergi makanan.

\section{KASUS}

Pasien wanita usia 44 tahun datang dengan keluhan banyak sariawan dalam rongga mulut hingga membuat pasien susah makan. Pasien mengatakan sariawan muncul sejak 2 minggu yang lalu. Pasien mengatakan sariawan yang muncul kemudian hilang kemudian muncul lagi. Pasien mengatakan sebelum sariawan badan pasien tidak panas.Pasien mengatakan sering mengalami sariawan hilang timbul sejak Pasien mengaku tidak memiliki penyakit sistemik. Pasien mengatakan dari riwayat keluarganya memiliki riwayat hipertensi tapi pasien mengaku tidak memiliki hipertensi dan sering memeriksakan tensi dan juga gula darah secara rutin. Pada pemeriksaan ekstra oral kelenjar submandibular teraba kenyal, lunak, dan tidak sakit. pada pemeriksaan klinis intra oral pada ventral, lateral lidah, gingiva, dan labial bawah terdapat ulcer, multiple, bentuk irregular, melahirkan 6 tahun yang lalu, sariawan sering muncul secara periodik 1-2 bulan sekali. Pasien mengatakan kadang sariawan yang muncul 2 buah kadang bisa lebih dari 5 buah, posisi terjadi sariawan pindah-pindah tapi pernah juga di posisi yang sama. Pasien mengatakan akhirakhir ini beban kerja di tempat kerjanya mengalami peningkatan. Pasien mengatakan sudah pernah memeriksakan ke dokter spesialis THT \pm 2 bulan yang lalu kemudian diperiksa tes virus tapi hasil negatif, pasien kemudian diberikan obat semprot, kemudian sariawan sempat sembuh tetapi kemudian muncul kembali. Selama ini pasien sudah pernah memakai enkasari, albotyl, dan kenalog. Pasien mengaku tidak suka makan buah dan sayuran. Pasien kemudian memeriksakan ke dokter gigi di poli gigi RSUA 2 hari yang lalu, kemudian dirujuk untuk melakukan pemeriksaan darah lengkap dan diberikan obat kumur povidone iodine kemudian dirujuk ke spesialis penyakit mulut. Pasien datang membawa hasil pemeriksaan darah lengkap dan ingin dirawat.

Pada pemeriksaan riwayat kesehatan pasien mengatakan tidak memiliki kebiasaan merokok, pasien mengaku tidak memiliki riwayat alergi baik pada dirinya maupun keluarga. ukuran bervariasi, warna keputihan dengan tepi kemerahan terasa sakit. (Gambar 1)

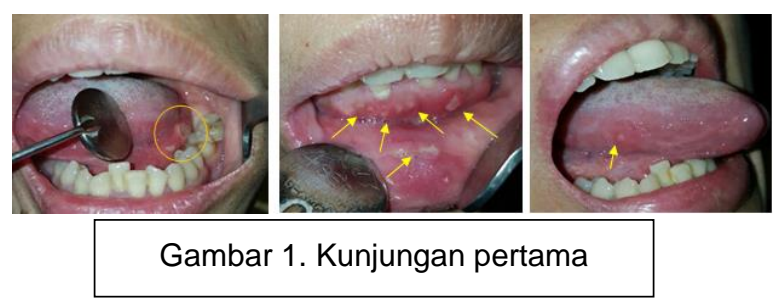


Hasil pemeriksaan darah lengkap tanggal 5 april 2017

\begin{tabular}{|c|c|c|}
\hline Parameter & Hasil & Nilai Normal \\
\hline Hemoglobin & 12,9 & $11,7-15,3 \mathrm{~g} / \mathrm{dl}$ \\
\hline Lekosit & 9,75 & $6-1210^{3} / \mu \mathrm{L}$ \\
\hline Trombosit & 421 & $150-44010^{3} / \mu \mathrm{L}$ \\
\hline Eritrosit & 4,18 & $3,8-5,210^{3} / \mu \mathrm{L}$ \\
\hline Hematocrit & 37,1 & $35-47 \%$ \\
\hline MCV & 88,8 & $80-100 f l$ \\
\hline MCH & 30,9 & $26-34 \mathrm{pg}$ \\
\hline MCHC & 34,8 & $32-36 \mathrm{~g} / \mathrm{dl}$ \\
\hline RDW & 12,5 & $11,5-14,5 \%$ \\
\hline MPV & 9,6 & $6,8-10 \mathrm{FI}$ \\
\hline Limfosit \% & $24,1 \mathrm{~L}$ & $25-40 \%$ \\
\hline Monosit \% & $9,7 \mathrm{H}$ & $2-8 \%$ \\
\hline Eosinofil \% & $1,3 \mathrm{~L}$ & $2-4 \%$ \\
\hline Basofil \% & 0,4 & $0-1 \%$ \\
\hline Neutrofil \% & 64,5 & $50-70 \%$ \\
\hline
\end{tabular}

Tabel 1. Hasil Pemeriksaan darah

Anamnesis dan pemeriksaan klinis pasien didiagnosis sementara suspect stomatitis alergika dengan diagnosis banding recurrent apthous stomatitis. Pasien kemudian diukur tensi dengan hasil 120/80 mmHg. Pada pasien dilakukan occlusal grinding pada gigi 11,21. Pasien juga diresepkan obat kumur Aloe vera ectract oral rinseyang dipakai 4 kali sehari. Pasien diberikan pengobatan dengan aloe vera extract gel pada ulcer. Pasien kemudian dirujuk untuk pemeriksaan IgE total. Pasien diinstruksikan untuk menggunakan obat secara teratur, pasien diinstruksikan untuk mulai banyak makan buah dan sayuran serta minum air putih yang cukup, pasien diinstruksikan menjaga kebersihan rongga mulut. kontrol seminggu kemudian.

\section{TATALAKSANA KASUS}

Pasien dirawat selama 6 minggu dengan 6 kali kunjungan. Pada kunjungan pertama pasien diukur tensi dengan hasil 120/80 $\mathrm{mmHg}$, kemudian pasien dilakukan occlusal grinding pada gigi 11, 21 dan pembersihan karang gigi. Pada kunjungan pertama pasien diberikan obat kumur Aloe Vera Ectract Rinse (Aloclair ${ }^{\circledR}$ Oral rinse) yang dipakai 4 kali sehari. Pasien kemudian dirujuk untuk melakukan pemeriksaan darah ( $\lg \mathrm{E}$ Total). Pada kunjungan kedua pasien membawa hasil pemeriksaan darah dengan hasil 642,98 ( $\mathrm{N}$ : <150). Pasien kemudian dirujuk untuk melakukan pemeriksaan alergi (Skin Prick Test). Pada kunjungan ketiga pasien membawa hasil tes HIV dengan hasil negative dan hasil tes alergi (Skin Prick Test) (Tabel 2).

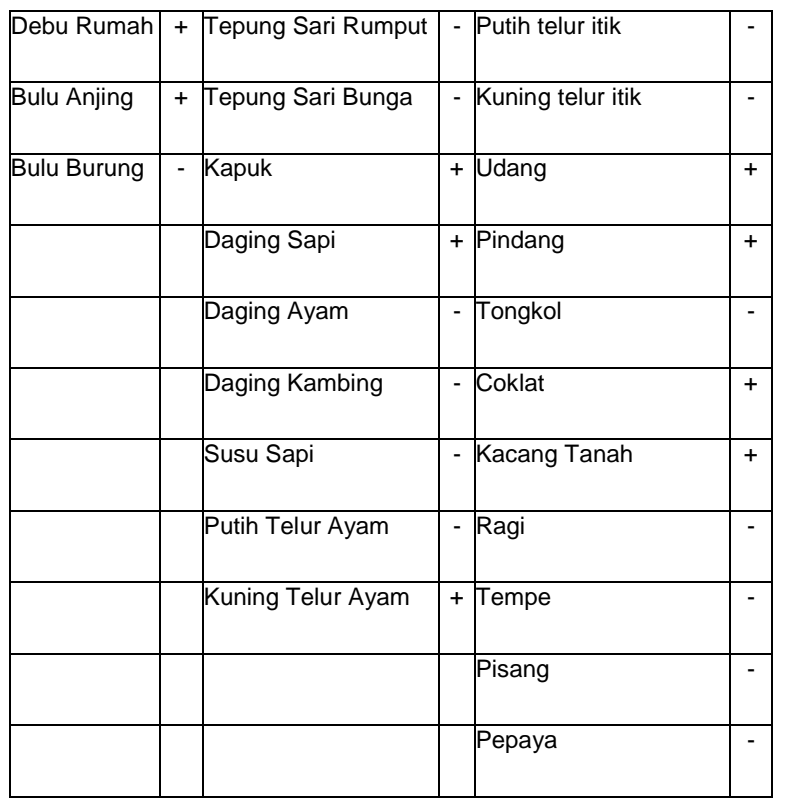

Tabel 2. Hasil Tes Alergi (Skin Prick Test) 
Setelah hasil pemeriksaan tes alergi (Skin Prick Test) pasien kemudian diberikan obat loratadine yang diminum $1 x$ sehari, methyl prednisolone $3 x$ sehari, hepaprotektor (Hepagard®) 1x sehari dan multivitamin (Becom-Zet ${ }^{\circledR}$ ) 1X sehari. Pasien kemudian dirujuk untuk melakukan pemeriksaan darah (Glukosa darah, SGOT, SGPT, Kreatinin) dengan hasil Glukosa darah puasa:76 ( $\mathrm{N}:<100)$, SGOT: 12,0 (N:0-35), SGPT: 13,1 (N: 0-35) dan Kreatinin $0,5(0,5-0,9)$. Pada kunjungan ke empat lesi sudah sembuh(Gambar 2).
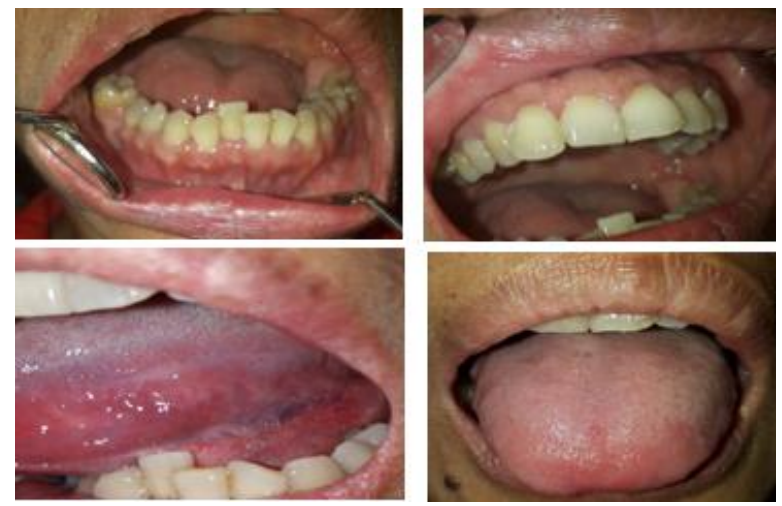

Gambar 2. Lesi sudah sembuh

Pada kunjungan ke empat dilakukan penurunan dosis (tapering of doses) pemakaian methyl prednisolone menjadi $2 x$ sehari dan kunjungan kelima menjadi $1 x$ sehari. Pada kunjungan ke enam pengobatan dihentikan. Pada setiap kunjungan pasien dilakukan pengukuran tensi dengan hasil 120/80 mmHg. Pasien diberikan instruksi untuk menjaga kebersihan rongga mulut dan menghindari makanan penyebab alergi.

\section{PEMBAHASAN}

Stomatitis alergika adalah suatu ulcer kambuhan yang mengenai epitel mukosa rongga mulut dan sudah melibatkan membrana basalis.
Secara umum memiliki ciri multiple, dasar lesi berwarna putih atau kuning, berpindah-pindah tempat, simtomatis, bersifat kambuhan dan bisa mengenai semua permukaan mukosa rongga mulut.Setelah dilakukan pemeriksaan penunjang, maka diagnosis akhir pasien ini adalah stomatitis alergika. Hal ini berdasarkan hasil pemeriksaan darah lgE total dan uji tusuk kulit (skinprick test). Pada pemeriksaan $\operatorname{lgE}$ total didapatkan hasil 642,98 dengan (nilai normal $<150 \quad \mathrm{KIU} / \mathrm{L}$ ) memberikan indikasi bahwa pasien ini memiliki bakat atau kecenderungan yang kuat untuk mengalami reaksi alergi sehingga pasien kemudian dirujuk untuk melakukan pemeriksaan uji tusuk kulit (skin prick test). ${ }^{4}$

Skin Prick Test adalah salah satu jenis tes kulit sebagai alat diagnosis yang banyak digunakan oleh para klinisi untuk membuktikan adanya lgE spesifik yang terikat pada sel mastosit kulit. ${ }^{5}$ Tes ini relatif mudah dan nyaman untuk pasien serta tidak mahal. Untuk dokter hasil pemeriksaan bisa didapatkan hanya dalam waktu 20 menit sehingga penjelasan bisa diberikan kepada pasien seketika itu juga. ${ }^{6}$

Mekanisme kerja dari skin prick test adalah dibawah permukaan kulit terdapat sel mast, pada sel mast didapatkan granula-granula yang berisi histamin. Sel mast ini juga memiliki reseptor yang berikatan dengan IgE. Ketika lengan $\lg \mathrm{E}$ ini mengenali alergen (misalnya house dust mite) maka sel mast terpicu untuk melepaskan granul-granulnya ke jaringan setempat, maka timbulah reaksi alergi karena histamin berupa bentol (wheal) dan kemerahan (flare). ${ }^{7}$ 
Pada hasil uji tusuk kulit (skin prick test) didapat hasil positif pada debu rumah, bulu anjing, kapuk, daging sapi, susu sapi, kuning telur ayam, udang, bandeng, pindang, coklat, dan kacang tanah. Pasien mengatakan menyukai daging sapi, telur ayam, udang, coklat, dan minum susu sapi dan memelihara anjing.

Alergi makanan sering melibatkan reaksi hipersensitivitas tipe 1 dan tipe 4 , maupun kombinasi keduanya. ${ }^{3,4}$ Pada kasus ini diduga merupakan reaksi hipersensitivitas tipe 1 lambat (2-24 jam setelah terpapar alergen), dimana alergen yang ada akan berikatan dengan APC melalui reseptor $\mathrm{FC} \varepsilon \mathrm{RI}$ (FC Epsilon Receptor), selanjutnya mengaktivasi $\mathrm{TH}_{1}$ yang kemudian akan mengaktifkan IFN-y. Ikatan alergen dengan APC juga akan mengaktivasi $\mathrm{TH}_{2}$, yang kemudian akan mengaktivasi IL-5 yang pada akhirnya akan mengaktifkan eosinofil. Eosinofil inilah yang menyebabkan kerusakan epitel. Reaksi hipersensitivitas tipe 1 lambat ini juga ikut dipengaruhi oleh sitokin dan chemokines yang dikeluarkan oleh sel mast

Pada kasus ini diagnosis bandingnya adalah Reccurent Aphthous Stomatitis (RAS), yaitu suatu ulcer berulang yang mengenai rongga mulut tanpa diketahui secara pasti penyebabnya. Penyebabnya sangat multifaktorial, dengan faktor predisposisi trauma, genetik, alergi, obat-obatan, hormonal, stres/cemas, dan sistem imun yang abnormal. . $^{3.11}$ Secara klinis gambarannya sama, hanya penyebabnya belum diketahui secara pasti, sementara stomatitis alergika penyebabnya sudah jelas yaitu alergi. Pada pasien diketahui mengalami stress yang diketahui dari anamnesis dan dari pemeriksaan darah dengan hasil eosinophil berada dibawah normal, dimana diketahui penurunan nilai eosinophil dapat terjadi pada saat tubuh merespon stress.

Pada kunjungan pertama pasien diberikan obat kumur aloe vera ectract yang dapat memberikan rasa nyaman dan mengurangi rasa sakit karena obat ini dapat membuat barrier pada permukaan lesi sehingga melindungi lesi dari paparan atau kontak bahan lain dengan saraf tepi pada lesi, selain itu asam hialuronat dan aloe vera pada obat ini berfungsi sebagai bahan untuk mendukung proses penyembuhan pada kerusakan jaringan mukosa rongga mulut. ${ }^{12}$

Pasien diberikan multivitamin (BecomZet) yang mengandung Vit E $30 \mathrm{iu}$, vit C $750 \mathrm{mg}$, vit $B 115 \mathrm{mg}$, vit $B 215 \mathrm{mg}$, vit B6 $20 \mathrm{mg}$, vit B12 $12 \mathrm{mcg}$, folic acid $400 \mathrm{mcg}$, pantothenic acid 20 mg, Zn 22.5 mg, niacin 100 mg. Fungsi dari masing-masing multivitamin dan mineral ini adalah vitamin $\mathrm{E}$ dan $\mathrm{C}$ berfungsi sebagai antioksidan, dan perbaikan sistem imun, mempercepat penyembuhan luka, pembentukan jaringan ikat., vitamin B1 (Tiamin), vitamin B2 (riboflavin), niacin berfungsi metabolisme karbohidrat, vitamin B6 (piridoksin) berfungsi untuk metabolisme protein dan glikogen., vitamin B12 (cobalamin) dan asam folat berfungsi untuk pembentukan sel darah merah, dan sintesis DNA, asam pantotenat berfungsi untuk sistesis lemak., zinc berfungsi untuk regenerasi sel, 
metabolisme karbohidrat, membantu mempercepat regenerasi jaringan yang rusak, meningkatkan proses penyembuhan luka. ${ }^{13}$

Setelah dilakukan skin prick test pasien diberikan metilprednisolon sebagai terapi simptomatis berfungsi sebagai antiinflamasi dan imunosupresi untuk meredakan ulserasi yang luas, eritema dan nyeri. Metilprednisolon termasuk kortikosteroid yang bersifat intermediate acting, mempunyai half-life 12-36 jam dan retensi natrium rendah sehingga dapat menurunkan kemungkinan timbulnya efek samping. Dosis yang diberikan dapat rendah atau tinggi sesuai tingkat keparahan penyakit untuk pengendalian penyakit. Mekanisme antiinflamasi yaitu adanya pelepasan lipokortin yang memiliki aksi inhibisi langsung terhadap fosfolipase A2 dalam sel dengan cara menginduksi proses fosforilasi enzim, menghambat pembentukan prostaglandin, leukotrin dan derivat jalur asam arakidonat. Kortikosteroid juga menghambat produksi dan pelepasan sitokin, termasuk interleukin (IL-1), IL6 dan tumor nekrosis factor (TNF- $\alpha$ ) makrofag, sel langerhans, monosit. Sitokin-sitokin ini terlibat dalam aktivasi sel $\mathrm{T}$ dan mencetuskan kaskade imunoreaktif. Pemberian kortikosteroid sistemik secara tapering-off untuk mencegah terjadinya efek withdrawal karena terdepresinya poros Hipotalamus-Pituitary-Adrenal yang bisa timbul apabila dilakukan penghentian secara tibatiba. ${ }^{14,15,16}$

Pemberian hepagard yang mengandung Silybum marianum dried extr $100 \mathrm{mg}$. Cynarae scol extr $50 \mathrm{mg}$, curcuma longa dried extr $20 \mathrm{mg}$ sebagai terapi suportif berfungsi sebagai hepatoprotektor melindungi liver dari efek samping pemberian kortikosteroid. ${ }^{13}$

Selain diterapi obat pasien juga diberikan edukasi dan instruksi untuk menghindari makanan yang menimbulkan alergi serta mencoba mengganti pola makan dengan makanan yang tidak menimbulkan alergi. Pada pasien juga diberikan instruksi untuk menjaga kebersihan rongga mulut. Pasien juga diinstruksikan untuk mulai makan buah dan sayuran serta minum air putih yang cukup untuk menjaga kesehatan tubuh.

\section{KESIMPULAN}

Stomatitis alergika merupakan suatu reaksi hipersensitivitas yang disebabkan oleh alergen. Untuk menegakkan diagnosis dibutuhkan anamnesis yang lengkap dan pemeriksaan penunjang. Keberhasilan pada kasus ini tidak hanya tergantung pengobatan tetapi juga dibutuhkan kerja sama yang baik antara pasien dengan dokter agar perawatan dapat dilakukan dengan tuntas.

\section{DAFTAR PUSTAKA}

1. Holgate Stephen $T$ et al. Allergy 4th ED. SAUNDERS an imprint of Elsevier Limited 2012.509.

2. Indrwati, E., Harijanti, K. Management of allergic stomatitisdue todailyfoodconsumption. Dentofasial, Vol.13, No.2, Juni 2014: 129-134.

3. Wardhana, E.A.D.Recurrent Aphthous Stomatitis Caused by Food Allergy (Review 
Article). Journal Acta Medica Indonesiana. 2010. 42(4). p 236:240

4. Tjokroprawiro A, Setiawan $P$, Efendi C, Santoso D, Soegiarto G. Buku Ajar Ilmu Penyakit Dalam. 2nd ed. Surabaya: Airlangga University Press; 2015;p.1-28

5. Pawarti DR. Tes Kulit dalam Diagnosis Rinitis Alergi, Media Perhati. Volume 10 2004; Vol 10 no $3: 18-23$

6. Krouse JH, Marbry RL. Skin testing for Inhalant Allergy 2003: current strategies. Otolaryngolo Head and Neck Surgary 2003; 129 No 4 : 34-9.

7. Lie P. An Approach to Allergic Rhinitis, Respirology \& Allergy Rounds. April 2004; 39 45

8. Valenta,R; Hochwallner, H; Linhart, B; Pahr, S. Food Allergies: The Basics. Journal of Gastroenterology.2015;148:p.1120-1131

9. Kumar,R; Abbas,AK;Aster,JC.Robbins and CotranPathologic Basis of Disease (ninth Edition). Philadelphia, USA: Elsevier Saunders.2015:200-206

10.Glick M. Burket's Oral Medicine. 12th ed. Connecticut (USA): People's Medical Publishing House; 2015; 4:73-77

11.DeLong L, Burkhart N. General and Oral Pathology for The Dental Hygienist. 2nd ed. Baltimore, MD: Lippincott Williams \& Wilkins; 2013;331-334,341-346,347-349

12.Kalbemed A. Aloclair Plus [Internet]. Kalbemed.com. 2013 [cited 7 April 2016]. Available from: http://www.kalbemed.com 13.MIMS.com. 114th ed. jakarta; 2009.
14.Lokanata MD. Pemakaian Glukokortikoid pada Pengobatan. 2006. Jakarta: EGC. Pp.8$13,15-40$

15.Dewoto HR. 2012. Farmakologi dan Terapi. Ed 5. Jakarta: FKUI.p 283,505

16.Sitompul R. Kortikosteroid dalam Tata Laksana Uveitis: Mekanisme Kerja, Aplikasi Klinis, dan Efek Samping. 2011. J Indon Med Assoc. Vol 61. p 265-9 